\title{
Effect of Applying Green Building Practices and Policies in Reducing Environmental and Health Impacts in the Construction Sector
}

\author{
Mansour Mahmoud Safran
}

\begin{abstract}
The present research aims at addressing the effect of applying green building policies and practices by the Jordanian construction firms in reducing environmental pollution and harmful health effects. To achieve the research objectives, the researcher depended on the descriptive analytical research design method because of its relevance to this kind of research. Data was collected through the use of previous researches to collect the secondary data, and the use of the questionnaire prepared by the researcher to collect the primary data, study population consisted of (10) Jordanian construction firms, while study sample consisted of (200) male and female heads of divisions in these firms (87) females and (113) males. For data analysis (SPSS) software in used to conduct the statistical processes. Results of these analyses were discussed and a number of recommendations offered to these firms to actively and meaningfully respond to the potential environmental possible of such negative impacts.
\end{abstract}

Keywords: Green Building, Environmental Pollution, Policies and Practices, construction Firms.

\section{INTRODUCTION}

This research aims to provide the clear indication about the effect of applying green building in reducing environmental Pollution and the harmful health effects caused by the Jordanian construction firms operating in the capital Amman city, For this purpose many researchers have been conducted and adapted to find out the most beneficial ways to reduce environmental pollution from the construction activities to save the environment and the economics of the country through the optimal usage of the scarce natural resources that the country is suffering from in terms of water and energy resources coupled with the growth of population becomes a very critical problem.

In Jordan as one of the developing countries with very limited resources with the increase in demands, there the urgent need to find alternative and efficient ways to compensate such shortage represent in the adoption and application of green building policies and practices (Omar, B et al., 2016).

A major consumer of the country's natural resources is the construction industry; also this industry is the major source of environmental pollution.

Revised Manuscript Received on June 15, 2020.

* Correspondence Author

Mansour Mahmoud Alsalem SAFRAN*, Jarash University

Dipartment of architecture E-mail: safranmansour@gmail.com

(c) The Authors. Published by Blue Eyes Intelligence Engineering and Sciences Publication (BEIESP). This is an open access article under the CC BY-NC-ND license (http://creativecommons.org/licenses/by-nc-nd/4.0/)
Also, construction activities are responsible of huge amounts of solid waste released in the environment (the world watch institute, 2012).

Jordan faces many challenges related to energy consumption, waste generation, water shortage, and many environmental issues, forcing the country to adopt and apply a number of up-to-date policies and practices to achieve sustainable development. The valuable solution is the inclination towards the adoption of green building policies and practices to help the country in achieving development and advancement (Al-Subeh, 2013).

\section{1-1 Research Problem}

Research problem emerges from the increasing attention and concern about the environmental pollution and health impacts cause by the practices of the construction firms in Jordan.

Since the construction processes involve many practices and procedures that have the high potential to cause deter mental impacts on the environment and on health of the nearby surrounding residents who will be the first to be affected by such negative practices.

\section{1-2 Research Questions:}

From the research problem stem the following sub-questions:

1. What is the effect of applying green building policies and practices on reducing environmental and health impacts by the Jordanian construction firms from the point of view of the head of divisions in these firms?

2. Are there differences with statistically significance at significance level $(\alpha \leq 0.05)$ in applying green building policies and practices in reducing environmental pollution and health impact in the Jordanian construction firms attribute to gender, Job experience, and scientific qualification?

\section{1-3 Importance of the Research:}

Importance of this research comes from the theoretical side represent in the information that will be reached from its sources relating to the green building policies and practices in an attempt to reduce the environmental pollution and health impacts. Also, importance of this research appears from being of the scarce researches that have addressed this topic in Jordan which constitutes additional scientific value to the Arab library.

\section{Published By:}

Blue Eyes Intelligence Engineering \& Sciences Publication

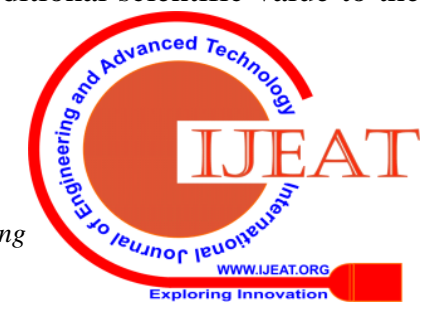


While from the practical side, it is hopeful that the following segments will benefit from it:

1. Researchers from making this present research a nuclear for similar researches with different variables, like energy saving and materials recycling.

2. Those who are interesting in the environmental pollution issues and its negative impact on human life and on natural resources.

\section{1-4 Objectives of the Research:}

This present research seeks to achieve the following objectives:

1. To show concepts of green building and environmental pollution.

2. To show the construction firms policies regarding the application of green building policies and practices.

3. To know degree of awareness about role of green building in reducing the negative impacts of pollution on the environment and health of the population.

\section{1-5 Hypothesis of Research:}

Ho: There are no differences with statistically significance at significance level $(\alpha \leq 0.05)$ of applying green building policies and practices in reducing the environmental pollution and health impacts by the Jordanian construction firms from the point of view of the firms' head of divisions.

Ho-1: There are no differences with statistically significance at significance level $(\alpha \leq 0.05)$ in applying green building policies and practices in reducing the environmental pollution and health impacts from the point of view of the firm's head of divisions attribute to gender.

Ho-2: There are no differences with statistically significance at significance level $(\alpha \leq 0.05)$ in applying green building policies and practices in reducing the environmental pollution and health impacts from the point of view of the firm's head of divisions attribute to Job experience.

Ho-3: There are no differences with statistically significance at significance level $(\alpha \leq 0.05)$ in applying green building policies and practices in reducing the environmental pollution and health impacts from the point of view of the firm's head of divisions attribute to Scientific Qualification .

\section{1-6 Model of the Research:}

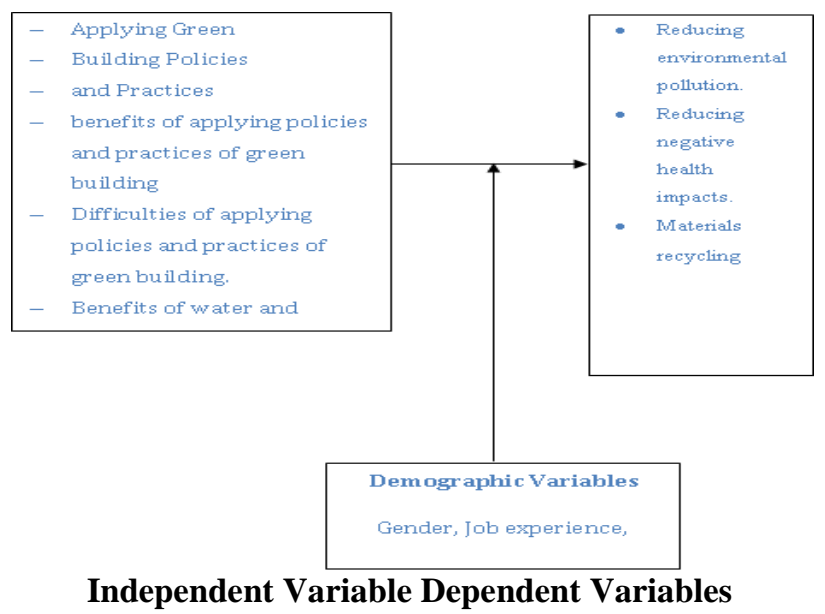

\section{1-7 Procedural Terms:}

Green Building: Green building concept includes sustainability, eco-friendly, energy- friendly (Ramioul, et al., 2016).

Green Building: Are buildings that through their lifecycle maximize the resource savings, protect the environment, reduce pollution, provide people with healthy, comfortable space, and harmony with the nature (Liu, 2012).

Green Building: Is a sustainable structure which is designed, constructed, and operated to minimize as possible waste and environmental pollution (Howe, 2010).

\section{1-8 Limitation of the Research:}

This research is limited to the following:

1. It is limited to its topic "Effect of applying Green building policies and practices in reducing environmental,

2. pollution and health negative impacts.

3. It is limited to the construction sector in Amman city.

4. It is limited to small sample size, making it difficult to generalize the results.

\section{LITERATURE REVIEW}

In a study conducted by (Zhang, et al, 2019), entitled “A Survey of the Status and Challenges of Green Building Development in various countries" aimed to deal with various problem the construction industry is facing, and the concept of green building has gradually shaped and developed, and the concept of green building covers a wide range of elements, and its definition is constantly updates as the construction industry develops, and how users interact with green building technology, because among the various causes of the problems the building construction industry has been criticized as being a leading exploiter of natural resources, it makes significant impact on the environment, society, economy, and human health.

(Matisoff, D et al., 2016) study entitled “Green Buildings:

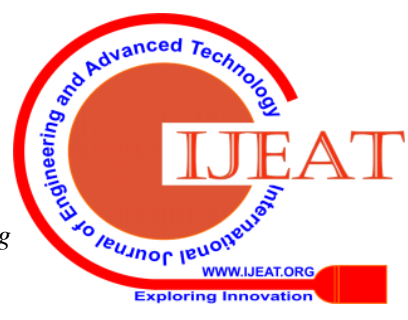


Economics and Policies" presents an overview of green building economics and polices through a survey of the theoretical and empirical evidence concerning green buildings, the focus of the study was on whole- building investments, and green building should be supported by policies, including voluntary and mandatory programs that affects the entire life of the building from design and construction to operation, by application of standards and building code and other technology- specific regulations.

Phoya, S. (2018) study entitled "Sustainable Construction Sites in Tanzania', Contractors' Practices and Their Perspectives" aimed at examining the nature of sustainable construction management practices implemented by construction phase for the purpose of mitigating environmental impacts, the study used the questionnaire to collect the primary data from site managers, results revealed that most implemented sustainable practices in construction sites include reuse of construction materials, separation of waste on site.

Based on the results, the study recommended effective training for contactors, providing them with up-to-date information about benefits of sustainable construction practices to improve sustainable construction practices.

\section{METHODOLOGY OF THE RESEARCH:}

This research depended on the descriptive analytical research design method because of its relevance to this kind of research.

\section{3-1 Study Population and Sample:}

Study population consisted of construction firms operating in the Capital Amman City.

\section{3-2 Study Sample:}

Consisted of (200) head of divisions from (10) construction firms in Amman.

\section{3-3 Data Collection Instruments:}

This research used the following data collection instruments:

- Secondary data was collected from review a set of researches, published Journals and articles.

- Primary data was collected through the use of a questionnaire prepared by the researcher to collect the responses of the study sample respondents.

3-4 Validity and stability of the questionnaire were affirmed through introducing it to a number of specialists in the construction field.

To extract stability coefficient Cronpach Alpha equation is used according to table (1)

Table (1) Cronpach Alpha Equation For Stability

\begin{tabular}{|c|l|c|}
\multicolumn{1}{c|}{ No. } & \multicolumn{1}{c}{ The Variable } & $\begin{array}{c}\text { Cronpach Alpha } \\
\text { Coefficient }\end{array}$ \\
\hline 1. & Applying policies and practices of green building & $\mathbf{0 . 8 5}$ \\
\hline 2. & Benefits of Applying policies and practices of green building. & $\mathbf{0 . 8 8}$ \\
\hline 3. & Difficulties of Applying practices and policies of green building. & $\mathbf{0 . 9 0}$ \\
\hline 4. & Reducing environment pollution. & $\mathbf{0 . 9 2}$ \\
\hline \hline 5. & Total stability coefficient. & $\mathbf{0 . 8 8}$ \\
\hline
\end{tabular}

Total stability coefficient (0.88) which is relevant to the It is clear from table (2) that the percentage of the males purposes for conducting the present research.

\section{DATA ANALYSIS:}

Analysis Results of the study:

Following is an illustration of the study results analysis:

1) Characteristics of the study sample:

First: Gender

Table (2) Distribution of the sample individuals according to Gender

\begin{tabular}{|c|c|c|}
\hline Category & Frequency & Percentage \\
\hline Males & 113 & $56.5 \%$ \\
\hline Females & 87 & $43.5 \%$ \\
\hline Total & 200 & $100 \%$ \\
\hline
\end{tabular}
$(43.5 \%)$ it is possible to explain that through the topic green building needs field work, which explains the high percentage of the males.

Job Experience:

Table (3) Distribution of the study sample according to Job experience

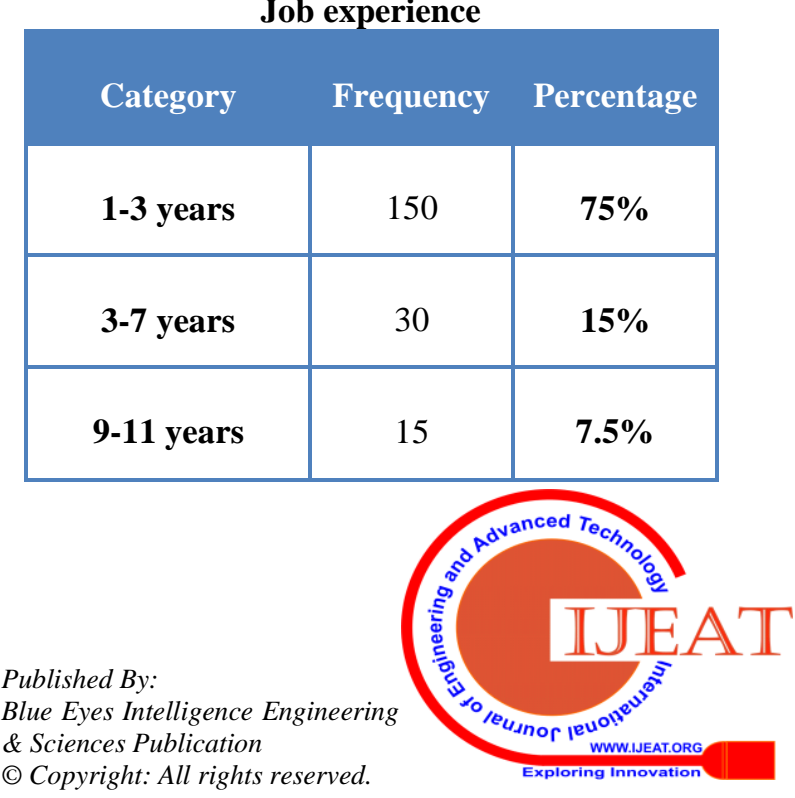


Effect of Applying Green Building Practices and Policies in Reducing Environmental and Health Impacts in the Construction Sector

\begin{tabular}{|c|c|c|}
\hline $\begin{array}{c}\text { More than 11 } \\
\text { years }\end{array}$ & 5 & $\mathbf{2 . 5 \%}$ \\
\hline \hline Total & 200 & $\mathbf{1 0 0 \%}$ \\
\hline
\end{tabular}

Table (3) shows that the highest percentage was for the category (1-3) years by $75 \%$, and the less percentage for the category (11) years and more by $2.5 \%$, it is possible to explain that since the employee, experience is measured through the years they worked in the construction firms.

Educational level:

Table (4) Distribution of the study sample according to educational level

\begin{tabular}{|c|c|c|}
\hline Category & Frequency & Percentage \\
\hline $\begin{array}{c}\text { Diploma and } \\
\text { less }\end{array}$ & 56 & $28 \%$ \\
\hline Bachelor & 79 & $39.5 \%$ \\
\hline
\end{tabular}

\begin{tabular}{|c|c|c|}
\hline Master & 20 & $\mathbf{1 0 \%}$ \\
\hline Doctorate & 45 & $\mathbf{2 2 . 5}$ \\
\hline \hline Total & $\mathbf{2 0 0}$ & $\mathbf{1 0 0 \%}$ \\
\hline
\end{tabular}

Table (4) shows that the highest percentage was for the bachelor category by (39.5\%), and the less percentage for the master category by (20\%), it is possible to explain that the work at the construction firms especially regarding the green building requires different scientific qualifications especially in the high category leading to work accuracy.

\section{Analyzing The Questionnaire Clauses}

Benefits of applying green building policies and practices: Means and standard deviations were extracted for benefit of applying green building policies and practices according to table (5).

Table (5) Means and standard deviations of benefits of applying green building policies and practices

\begin{tabular}{|c|l|c|c|c|} 
No. & \multicolumn{1}{|c}{ The Clause } & Means & $\begin{array}{c}\text { Standard } \\
\text { Deviation }\end{array}$ \\
\hline $\mathbf{1}$ & $\begin{array}{l}\text { Heads of divisions and employees are fully aware about benefits of } \\
\text { applying green building policies and practices. }\end{array}$ & 3.93 & 0.794 \\
\hline $\mathbf{2}$ & $\begin{array}{l}\text { Green building policies and practices reduce or eliminate negative impacts, } \\
\text { and can create positive impact on the climate and natural environment. }\end{array}$ & 3.00 & 1.029 & Medium \\
\hline $\mathbf{3}$ & $\begin{array}{l}\text { Green building policies and practices create environmentally responsible } \\
\text { and resource efficient usage. }\end{array}$ & 4.30 & 0.805 & High \\
\hline $\mathbf{4}$ & $\begin{array}{l}\text { Sustainable green buildings contribute in some way to preserving the } \\
\text { environment }\end{array}$ & 2.88 & 1.046 & Medium \\
\hline $\mathbf{5}$ & $\begin{array}{l}\text { Sustainable green building contributes to the idea of the well-being of the } \\
\text { occupants. }\end{array}$ & 3.69 & 1.046 & High \\
\hline $\mathbf{6}$ & $\begin{array}{l}\text { Green building policies and practices mean using and introducing } \\
\text { available resources, minimizing energy consumption and preserving the } \\
\text { environment. }\end{array}$ & 4.31 & 0.604 & High \\
\hline \hline
\end{tabular}

Table (5) shows that values of the means and standard deviations for the dimension benefits of applying green building policies and practices came at high level with mean (3.69) and standard deviation (0.86), at the first rank came clause (6) which states " Green building policies and practices mean using and introducing available resources, minimizing energy consumption and preserving the environment" with mean (4.31) and standard deviation (0.604), and at the last rank came clause (4) which states "
Sustainable green buildings contribute in some way to preserving the environment" with mean (2.88) and standard deviation (1.046) it is possible to explain that through using green building has great importance regarding providing added value and reducing energy consumption and preserving the environment from pollution which confirms importance and effectiveness of applying green building policies and practices. Difficulties facing the construction companies in applying green building policies and practice.

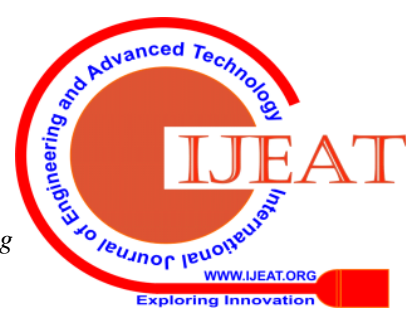


Table (6) Means and standard deviations of the difficulties facing the construction companies in applying green building policies and practices

\begin{tabular}{|c|l|c|c|c|} 
No. & \multicolumn{1}{|c}{ The Clause } & Means & Standard \\
Deviation & Level \\
\hline $\mathbf{7}$ & $\begin{array}{l}\text { Applying green building and practices requires special skills in using to } \\
\text { modes technology. }\end{array}$ & 4.32 & 0.737 & High \\
\hline $\mathbf{8}$ & $\begin{array}{l}\text { Applying green building policies and practices requires employees } \\
\text { training and education programs. }\end{array}$ & 3.89 & 0.803 & High \\
\hline $\mathbf{9}$ & Applying green building policies and practices is costly. & 3.98 & 0.738 & High \\
\hline $\mathbf{1 0}$ & $\begin{array}{l}\text { Applying green building policies and practices requires high level of } \\
\text { harmony with local climate, traditions, culture and surrounding } \\
\text { environment. }\end{array}$ & 4.54 & 0.556 & High \\
\hline $\mathbf{1 1}$ & $\begin{array}{l}\text { Applying green building policies and practices is a challenging task to } \\
\text { protect the environment and to reduce pollution to achieve healthy } \\
\text { comfortable and efficient use of space. }\end{array}$ & 3.28 & 1.093 & Medium \\
\hline \hline & \multicolumn{1}{|c|}{ Total Mean } & $\mathbf{4 . 0 0}$ & $\mathbf{0 . 7 8}$ & High \\
\hline
\end{tabular}

Table (6) shows that values of the means and standard deviations for the dimension difficulties facing the construction firms in applying green building policies and practices came at high level with mean (4.00) and standard deviation (0.78), at the first rank came clause (10) which states "Applying green building policies and practices requires high level of harmony with local climate, traditions, culture and surrounding environment" with mean (4.54) and standard deviation (0.556), and at the last rank came clause (11) which states "Applying green building policies and practices is a challenging task to protect the environment and to reduce pollution to achieve healthy comfortable and efficient use of space" with mean (3.28) and standard deviation (1.093) it is possible to explain that through the presence of a number of difficulties facing the application of green building policies and practices regarding the cost, and lock of support from the government which requires more support to the firms in applying green building policies and practices.

Benefits of Water and Energy from applying green building policies and practice.

Table (7) Means and standard deviations of water and energy benefits from applying green building policies and practices

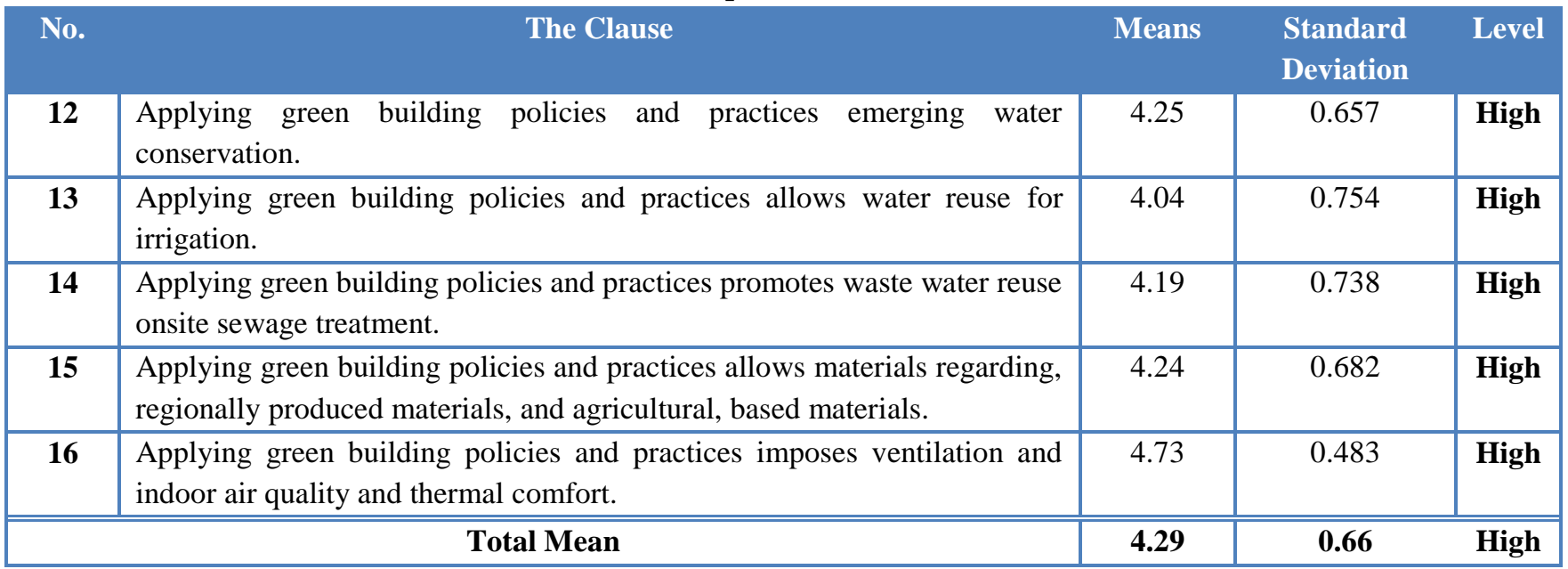

Table (7) shows that values of the means and standard deviations were at high level with mean (4.29) and standard deviation (0.66), clause (16) which states "Applying green building policies and practices imposes ventilation and indoor air quality and thermal comfort" at the rank with mean (4.73) and standard deviation (0.483) at the last rank came clause (13) which states "Applying green building policies and practices allows water reuse for irrigation" with mean (4.04) and standard deviation (0.754).

It is possible to explain that through applying green building policies and practices preserves water consumption and energy saving protecting the air from pollution which requires the application of green building policies and practice.

\section{Testing the Study Hypotheses:}

Result of testing the first hypothesis which states "There are no differences with statistically significance at significance level $(\alpha \leq 0.05)$ of applying green building policies and practices to reduce effects of the environmental pollution and health impacts by the Jordanian construction companies from the point of view of the heads of divisions and the

\section{Published By:}

Blue Eyes Intelligence Engineering \& Sciences Publication

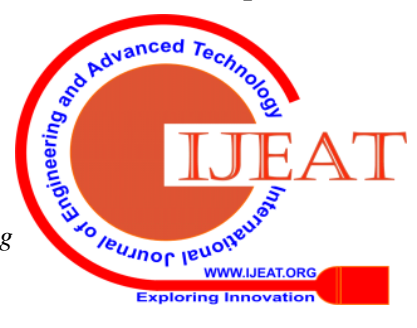


employees at these companies".

To answer this hypothesis t-test sample has been used according to table (8).

Table (8) Results of t-test sample for the first hypothesis

\begin{tabular}{c|c|cc|} 
T-calculated & t-tabulation & Sig. T & $\begin{array}{c}\text { Results of } \\
\text { the } \\
\text { hypothesis }\end{array}$ \\
\hline $\mathbf{2 4 . 3 5 9}$ & $\mathbf{1 . 9 6}$ & $\mathbf{0 . 0 0}$ & Rejection \\
\hline
\end{tabular}

One sample T-test is used, it is found from reviewing the results in the previous table that $\mathrm{T}$-calculated value reached (24.359) which is greater than its tabulated value, so there is an effect with statistically significance at significance level $(\alpha \leq 0.05)$ for applying green building policies and practices from the point of view of the heads of divisions and employees at the construction firms.

It is possible to explain that through the importance of applying green building policies and practices through the advantages that contribute greatly to cost reduction, pollution reduction, and preserving water and energy sources.

Result of testing the second hypothesis which states "There are no differences with statistically significance at significance level $(\alpha \leq 0.05)$ of applying green building policies and practices to reduce effects of the environmental pollution and health impacts attribute to gender, Job experience and scientific qualification".

Table (9) Test of independent samples for the gender variable influence in reducing the environmental and health

\begin{tabular}{|c|c|c|c|c|c|c|}
\hline Gender & Number & Mean & S.D & T-value & $\begin{array}{c}\text { Freedom } \\
\text { degree }\end{array}$ & $\begin{array}{c}\text { Significance } \\
\text { level }\end{array}$ \\
\hline Males & 113 & 2.26 & 0.866 & 2.992 & 199 & $\mathbf{0 . 0 3 *}$ \\
\hline \hline Females & $\mathbf{8 7}$ & $\mathbf{1 . 9 9}$ & $\mathbf{0 . 8 6 2}$ & & & \\
\hline
\end{tabular}

From T-value we notice that it is with statistically significance, which means that there are differences with statistically significance at significance level $(\alpha \leq 0.05)$ in applying green building policies and practices to reduce effects of environmental pollution and health impacts attribute to gender and in favor of the males it is possible to explain that through the different point of views of the samples individuals were variant and came in favor of the males, since the practice more in the construction field than the females, and more able to understand advantages of green building.

Job Experience:

Table (10) Results of uni-variance analysis for the difference in mean of the study sample individuals' answers attribute to Job experience

\begin{tabular}{|c|c|c|c|c|c|}
\hline $\begin{array}{c}\text { Source of the } \\
\text { variance }\end{array}$ & $\begin{array}{l}\text { Sum of the } \\
\text { squares }\end{array}$ & Freedom degrees & $\begin{array}{l}\text { Mean of } \\
\text { squares }\end{array}$ & $\mathbf{F}$ & Significance \\
\hline Between the groups & 1.224 & 3 & 0.410 & 1.350 & 0.259 \\
\hline Inside the groups & 104.982 & 196 & 0.305 & & \\
\hline Total & 105.106 & 199 & & & \\
\hline
\end{tabular}

Table (10) shows that (F) statistical value reached (1.350) which is insignificant at significance level, it is possible to explain that the study sample individuals regardless of

experiences do not disagree about the presence of benefits of applying green building policies and practices.

Table (11) Results of uni-variance analysis for the difference in mean of the study sample individuals' answers attribute to Scientific Qualification

\begin{tabular}{|c|c|c|c|c|c|}
\hline $\begin{array}{c}\text { Source of the } \\
\text { variance }\end{array}$ & $\begin{array}{l}\text { Sum of the } \\
\text { squares }\end{array}$ & Freedom degrees & $\begin{array}{l}\text { Mean of } \\
\text { squares }\end{array}$ & $\mathbf{F}$ & Significance \\
\hline Between the groups & 90.14 & 3 & 3.06 & 1.350 & 0.00 \\
\hline Inside the groups & 97.46 & 196 & 0.25 & & \\
\hline Total & 88.69 & 199 & & & \\
\hline
\end{tabular}

Table (11) shows that (F) statistical value reached (13.33) which is significant at significance level, it is possible to explain that the study sample individuals differ in their point of view regarding the importance and benefits of green building according to their scientific qualification and what they have learned at the university. 


\section{RECOMMENDATIONS AND CONCLUSION}

In light of the results, the researcher recommending the follow:

1. Necessity for setting national strategy for the application of green building, by building complexes of buildings to protect the environment from the pollution.

2. Necessity for the government to support the firms that perform green building to be able to execute green building projects covering great segment of the society.

3. The need for reducing the tasks imposed on green building to motivate the construction firms to be engaged in green building.

4. The need for providing training and education courses for the employees at the construction firms.

\section{REFERENCES}

1. Omar, B., Hiyassat, M., Sweiss, J \& Abdallah, A. (2016). Evaluation of Green Building Awareness in the Construction Industry: The Case of Jordan Interdisciplinary Environmental Review, Vol. 17, No. 3, PP. 209-231.

2. The World Watch Institute (2012). "Light green to sustainable buildings, Moving towards sustainable prosperity, PP. 129-136, Island Press, Washington.

3. Al-Subeh, M. (013). "A Strategic Framework for Sustainable Construction in Jordan Civil and Environmental Research, vol. 3, No. 2, PP: 102-107.

4. Ramioul, M., Benders, J \& Peteghem, V. (2016). "Green Construction and Team designs: Low Road and High Road to build energy friendly houses" World Review of Entrepreneurship, Management and Sustainable Development, Vol. 12 No. 1, PP. 33-44.

5. Liu, Y. (2012). Green Building Development in China, Mater Thesis, Lund University, Sweden.

6. Howe, J. (2010). "Overview of Green Buildings, National Wetland Newsletter, Vol. 33, No. 1, PP. 314

7. Zhang, Y., Wang, H \& Zhou, N. (2019). A Survey of the status and challenges of Green Building Development in Various Countries. Sustainability, Vol. 11, PP. 1-29.

8. Matisoff, D., Douglas, S \& Flowers, M. (2016). Green Buildings: Economics and Policies. Review of Environmental Economics and Policy, Vol. 0 Issue 0 PP. 1-19.

9. Phoya, S. (2018). Sustainable Construction Sites in Tanzania: Constructors' Practices and their Perspectives, International Journal of Construction Engineering and Management, Vol. 7, No. 2, PP. 88-96.

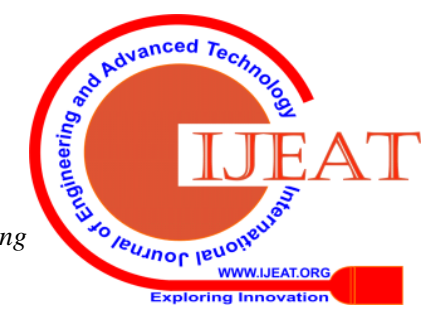

